\title{
Analysis of Heat Transfer Characteristics by Material Based on Closed Conditions Using Acrylic Hemispheres (II): Comparison by Type of Building Structural Materials ${ }^{1}(\mathbb{R}: \operatorname{Rip}$
}

\author{
Seung Min $\mathrm{YANG}^{2} \cdot$ Jun Hyuck $\mathrm{KWON}^{2} \cdot$ Phil Lip $\mathrm{KIM}^{2} \cdot \operatorname{Seog}$ Goo KANG(D) ${ }^{2, \dagger}$
}

\begin{abstract}
This study used a building model made up of cement, brick, and wood to measure temperature and relative humidity for 3 days in a closed environment with a diameter of $900 \mathrm{~mm}$, and performed a comparative analysis of the effect of types of building materials on the indoor temperature environment and heat transfer characteristics. The water installed inside the building model represented the person in the room and was used to assess how the environment effects the person. Wooden building model showed the lowest heat loss due to the higher thermal insulation properties than cement and brick buildings. The thermal comfort of each building model was calculated using temperature and relative humidity, and the wooden building model created a more pleasant environment than the cement and brick building models.
\end{abstract}

Keywords: finishing material (wood), temperature, humidity, comfort, heat transfer mode

\section{INTRODUCTION}

As various materials are being used as building materials in Korea and other countries around the world these days, a distinct indoor environment is shown in each region. Usually, the East and West show differences in building materials used depending on characteristics of local climate, environment and culture.

Architectural styles using stone materials are dominantin Europe as stone culture has been developed from the region throughout the history, while wooden houses using wood are dominant in the United States due to abundant forestall resources. Among East Asian regions, Japan shows high proportion of wooden houses with excellent seismic performance, in addition to high-rise buildings built of reinforced concrete due to the geographical characteristics associated with frequent earthquakes. According to the Ministry of Land, Infrastructure and Transport's statistics on construction performance by housing type, a total of 765,328 houses were built as of 2015, of which 534,931 apartments (69.9\% of the total housing construction performance) were built. This means that more than $70 \%$ of all residential buildings are constructed as reinforced-con-

${ }^{1}$ Date Received September 2, 2019, Date Accepted August 31, 2020

2 Department of Biobased Materials, College of Agriculture and Life Science, Chungnam National University, Deajeon 34134, Republic of Korea

† Corresponding author: Seog-Goo KANG (e-mail: lachesis@cnu.ac.kr, ORCID: 0000-0002-2440-7070) 
Analysis of Heat Transfer Characteristics by Material Based on Closed Conditions Using Acrylic Hemispheres (II): Comparison by Type of Building Structural Materials

crete apartments. However, as public interest in the release of indoor air pollutants such as indoor formaldehyde and volatile organic compounds, etc. from building materials (Jang et al., 2007) has increased recently, the residential culture has changed in the direction that consumers value eco-friendly environment and indoor comfort. This is leading to an increase in demand for detached houses (Jang, 2018). The structure types of detached houses in Korea are divided into masonry, reinforced concrete, and wooden houses, and masonry houses are the most widely used structural type as they have the advantages of durability and fire resistance. However, they also have the disadvantage of poor capacity of controlling temperature and humidity. Reinforced concrete, which is widely used in the construction of apartments and multi-unit dwellings, is the most generalized housing structure due to its excellent structural stability. There are few construction cases for detached houses constructed with reinforced-concrete structures (Kim et al., 2017), which is related to the structure of low-energy buildings in Korea (registered in the Passive House Association). 56 cases of wooden structure account for the largest ratio (55.4\%) in total of 101 cases, followed by 37 cases of reinforced concrete $(36.6 \%), 6$ cases of steel frame $(5.9 \%)$, and 2 cases of hybrid structure $(2 \%)$, indicating that the ratio of reinforced concrete structures is lower than that of wooden structures (Lee, et al., 2018).

Wooden houses use wood as the major structural member as it can be seen in traditional Korean houses, and are drawing attention as a green building structure through research findings that it can have a positive impacton occupants with excellent insulation and humidity control (Kim et al., 2013). Wood, the main material of wooden houses, is noted as one of the sustainable resources and energy-efficient materials as a building material (Seo et al., 2016; Seo et al., 2017; Jang et al., 2017; Jang et al., 2017; Ozcan et al., 2019;
Pang et al., 2017; Yang et al., 2020). In addition, the cases of using wood isincreasing for various structural materials, interior and exterior finishing materials, and various composite materials such as furniture flooring, etc.(Chang, 2003) Therefore, this study used acrylic hemispheres for three major domestic architectural structures: concrete, masonry, and wooden houses, in order to compare and analyze the characteristics of building materials through derivation of the heat transfer method between building structures based on floor heating by ondol and the insulation performance of the internal and external temperature differences of the architectural structure which limits the influence of climatic variables such as wind direction and rainfall, etc.

\section{MATERIALS and METHODS}

\subsection{Testing materials}

In this study, cement, brick, and wood, which are major domestic building materials, were used to analyze the insulation and heat transfer methods based onthe type of building structural material in a closed condition using a hemisphere, and $360 \mathrm{~mm} \times 230 \mathrm{~mm}$ $\times 174 \mathrm{~mm}$ (internal volume $240 \mathrm{~mm} \times 110 \mathrm{~mm} \times$ $114 \mathrm{~mm}$ ) sized building model was produced. The wall thickness of the building model produced at this time was $38 \mathrm{~mm}$.

\subsubsection{Cement}

The cement powder from Company "H"based in Gyeongsangnam-do was used, which is a household cement that can be used without sand mixing. In order to produce the same size as a building structure made of other materials, a molding frame (outside: $436 \mathrm{~mm}$ $\times 3,060 \mathrm{~mm} \times 250 \mathrm{~mm}$, inside: $360 \mathrm{~mm} \times 230 \mathrm{~mm}$ $\times 174 \mathrm{~mm}$ ) was produced and utilized, and the building model produced through a curing period of two weeks after production was used in this study. 


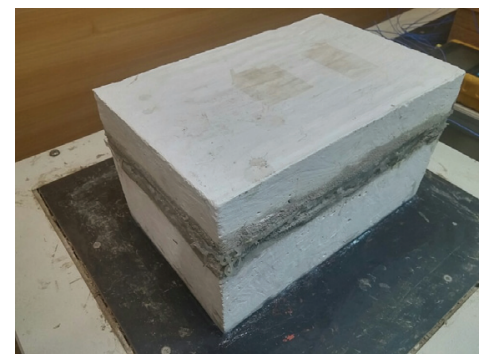

Fig. 1. Cement building model.

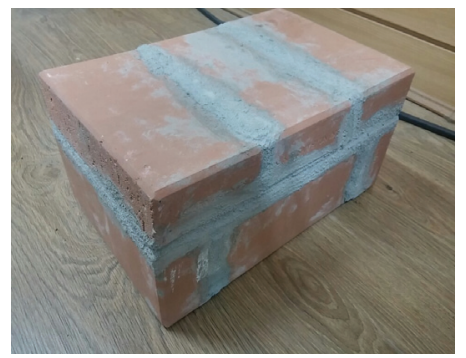

Fig. 2. Brick building model.

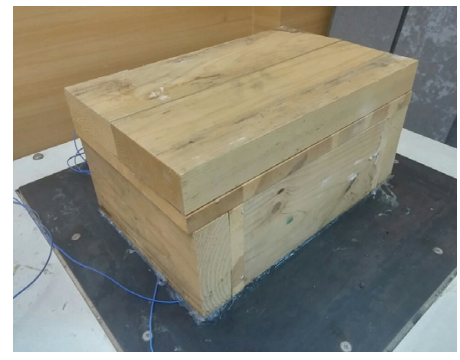

Fig. 3. Wood building model.

\subsubsection{Brick}

The bricks used for domestic masonry construction were received from Company " $\mathrm{T}$ " located in Daejeon and utilized, and the building model produced after a two-week curing period was used in this study after bonding the bricks with the cement used for concrete structures.

\subsubsection{Wood}

Fir (fir wood) of 2" $\times 4$ " $(38 \mathrm{~mm} \times 89 \mathrm{~mm})$ standard, which is the basic material of a light-weight lumber house, was used, and a building model was produced by using leg screws was used in this study. In order to prevent heat loss from the joint gap of the lumber, $3 \mathrm{M}$ Extreme Sealing tape $4411 \mathrm{~N}$ was used to apply a finish on top of the joint gap.

\subsection{Method of insulation test of building model using acrylic hemisphere}

The building (concrete, brick, wood) models were installed at the same location within three hemispheres, and temperature sensors were installed at five points to measure temperature changes in the interior and exterior of the building structure over time. The locations of the temperature sensor are shown in Fig. 4. In order to eliminate the effects of the ambient air on the produced building structure, this study was conducted by installing it within the transparent acrylic hemispheric space with a diameter of $900 \mathrm{~mm}$ and a thickness of $9 \mathrm{~mm}$.

The produced model was installed outdoors at Chungnam National University, and temperature changes such as temperatures of the hemisphere's interior and exterior, and ambient air temperature
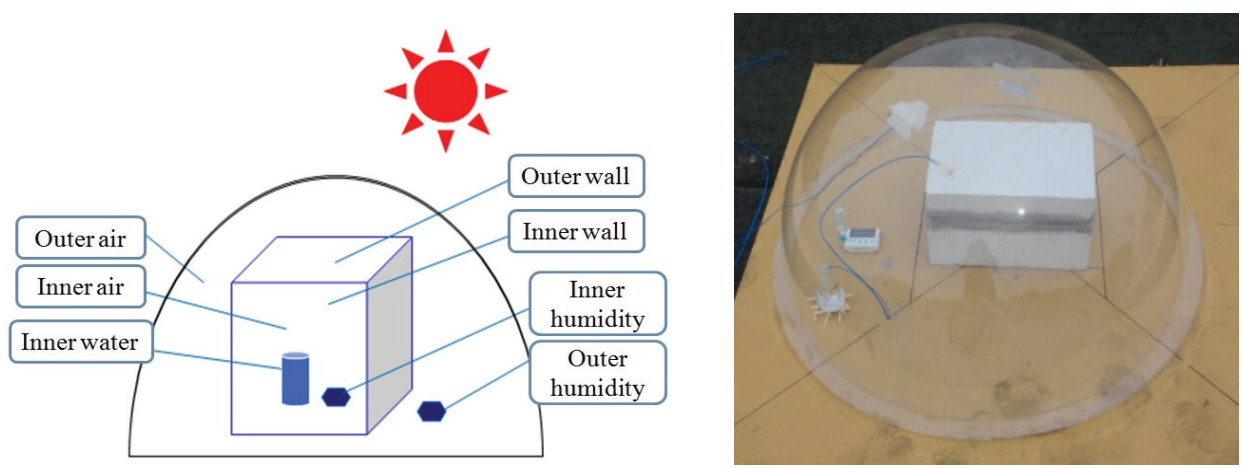

Fig. 4. Diagram of semi-sphere experiment. 
Analysis of Heat Transfer Characteristics by Material Based on Closed Conditions Using Acrylic Hemispheres (II): Comparison by Type of Building Structural Materials

inside and outside the model, etc. were measured over time for 3 days (between $8^{\text {th }}-10^{\text {th }}$ June, 2017). At this point, the temperature measurement cycle was $10 \mathrm{mi}-$ nutes and the measurement was performed using a thermal data logger (BTM-4208SD, Lutron).

\subsection{Test methodology for comparison of thermal transfer type of building model using ondol panel}

Inside each building model of $360 \mathrm{~mm} \times 230 \mathrm{~mm}$ $\times 174 \mathrm{~mm}$, made of wood, bricks, and cement respectively, a beaker with $50 \mathrm{ml}$ of water was installed $5 \mathrm{~cm}$ from the center of the building model's ceiling using a piano string, allowing the water to drop from it. After installing the thermal data logger (BTM-4208SD, Lutron) at 7 temperature measuring points (internal air, inner wall surface, water bottle surface, inside water, outer wall surface, and external air) as shown in Fig. 5, the structure was installed on an electric ondol panel (Sambo Electric Ondol Panel UH-A) and sealed with silicon. After setting the temperature of the ondol panel to $40^{\circ} \mathrm{C}$, the temperature measurement was initiated as the heating began, 3 hours of heating and 3 hours of cooling (non-heating) processes were repeated twice. In other words, the temperature was measured every 10 minutes for a total of 12 hours. The heating and cooling process were conducted to simulate 12 hours solar heating (daytime) and 12

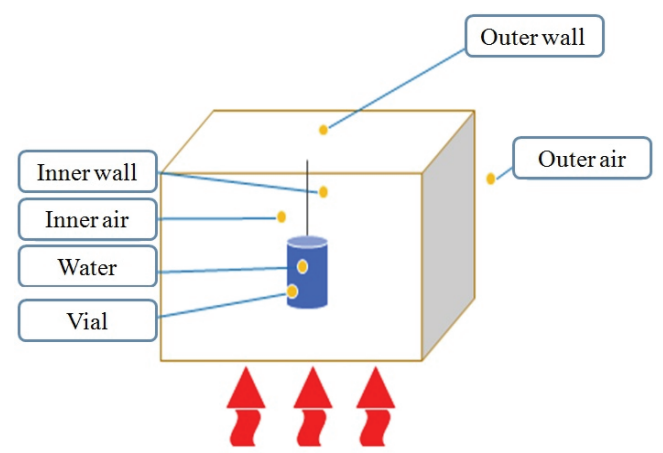

Fig. 5. Diagram of electric heat panel experiment. hours cooling (nighttime) based on 24 hours of a day. In particular, the test aimed to analyze heat transfer characteristics in the water model of the building structure through the highest-lowest temperature difference caused by heating and cooling. At this point, the experiment was carried out in a space at a temperature of $20 \pm 3^{\circ} \mathrm{C}$ without solar radiation.

\section{RESULTS and DISCUSSION}

\subsection{Insulation test result of building model using acrylic hemisphere}

\subsubsection{Comparison of temperatures on outer and inner walls of building by material}

For each type of building model, the air temperature in the hemisphere did not show any difference based on the type of building structural material, and the temperatures inside the hemisphere and the outer wall of the building model are shown in Fig. 6, and the internal temperature of the building model is shown in Fig. 7. The rise and fall of the temperature graph of the outer and inner walls of the building structure over time showed the same trend. However, the temperature of the exterior wall of the building model was highest for masonry structure, followed by concrete building, and wooden building. In addition, the difference between maximum and minimum temperatures was the largest for masonry, followed by concrete, and wood, which was the same order with that of the outer wall temperature. The difference between the maximum and minimum temperatures of the outer wall of the building was confirmed by the increased temperature of the building due to solar radiation and the decreased temperature of the outer wall of the building without solar radiation. The results were believed to indicate that the difference in heat transfer from the outer to inner wall between building materials was caused by the thermal conductance of the building material under the same condition of solar radiation. 


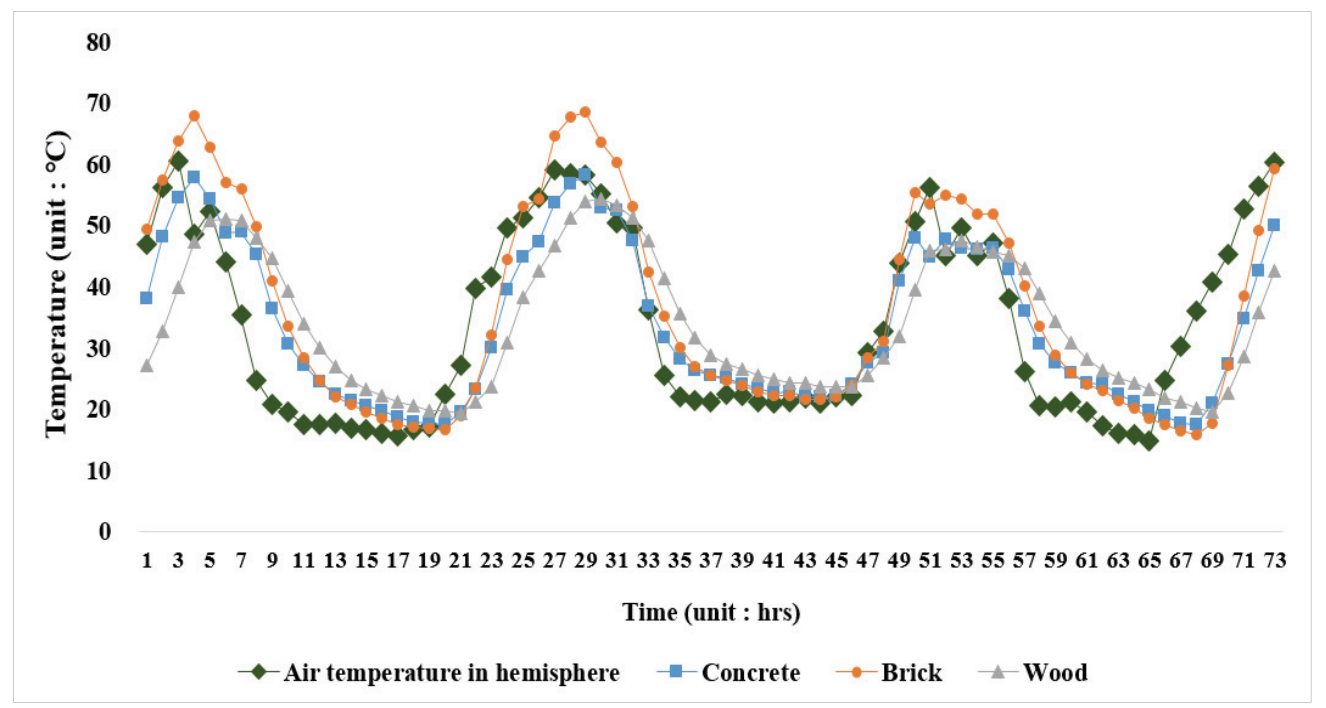

Fig. 6. Outer walls temperature of each building model.

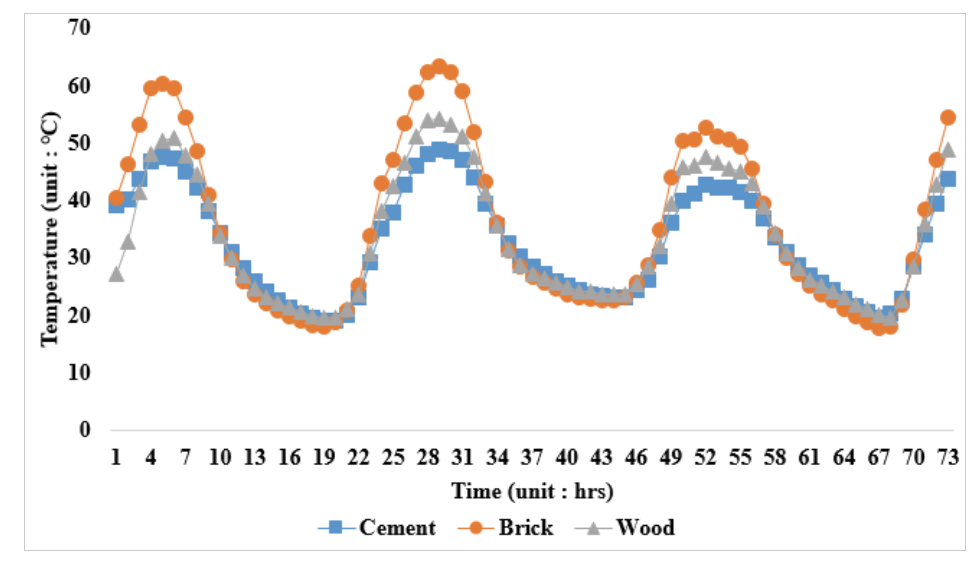

Fig. 7. Inner walls temperature of each building model.

\subsubsection{Comparison of temperature difference between outer and inner walls by material}

For the evaluation of insulation performance by material, the temperature difference between outer and inner walls by material is shown in Fig. 8. The difference in temperature between the outer and inner walls of each material refers to the insulation performance of the building structure. Insulation refers to the de- gree to which heat transfer is prevented, that is, the degree to which the temperature of the inner wall is less effected when the temperature of the outer wall increases. It can be interpreted that the higher the temperature difference between the outer and inner walls, the higher the insulation property (Yang et al., 2013). The degree of temperature difference between the outer and inner walls was indicated in the order of wood (approximately $40^{\circ} \mathrm{C}$ ) $>$ concrete $\fallingdotseq$ masonry 


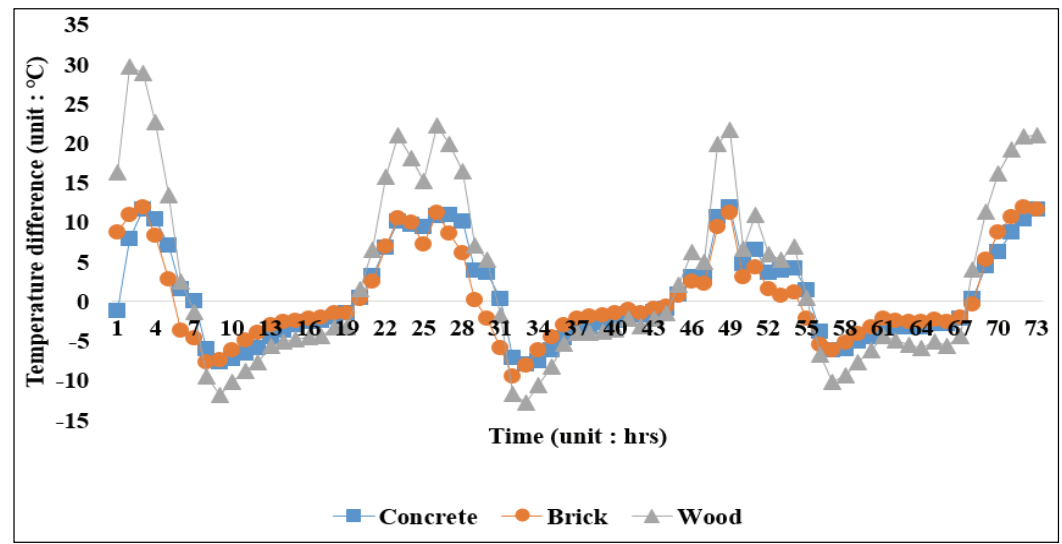

Fig. 8. Inner-outer temperature difference of each building model.

(approximately $20^{\circ} \mathrm{C}$ ), indicating that the wooden model has a less amount of heat transferred inside although it receives the same amount of heat as cement and concrete structures. The insulation performance of wood is determined to be higher than that of masonry and concrete, which is closely related to the thermal conductivity of each material. The heat conductivity of wood is $0.1-0.2 \mathrm{~W} / \mathrm{m} \cdot \mathrm{K}$, which is lower than that of bricks $0.4-0.8 \mathrm{~W} / \mathrm{m} \cdot \mathrm{K}$ and concrete $0.15-2.5$ $\mathrm{W} / \mathrm{mmK}$, thus having a relatively higher insulation performance (Park et al., 2012). In addition, since the thickness of the structure in the building model is the same for wooden, concrete, and brick, the thermal transmittance is closely related to the thermal conductivity of the raw materials in the structure, which can infer the same result as the temperature difference between the outer and the inner walls.

\subsection{Comparison of heat transfer methods by building materials using ondol panels}

Through the results of the thermal insulation test of the building model using the acrylic hemisphere, the difference in insulation performance caused by the dif- ference in internal and external temperature of each building material was confirmed. Moreover, three different building structures for comparing the heat transfer methods by building material based on floor heating and thermal comfort of the indoor occupants were used to compare the heat transfer method and the amount of energy applied to the glass bottle and water. The result of the amount of heat transferred based onthe heat transfer method during heating is the same as the result calculated by the calculation formula in Table 1 (Lee et al., 2009), and out of the amount of heat generated (theamount of heat generated by ondol panels: $55 \mathrm{~W})$, about $18 \mathrm{~W}(32.8 \%)$ was transferred to wood structures, $11.9 \mathrm{~W}(23.8 \%)$ to concrete structures and $12.503 \mathrm{~W}(22.7 \%)$ to masonry structures. The heat was transferred in the form of radiation, convection, and conduction in all materials, and the conduction heat was as low as about $1 \%$ of the total, and convective heat was about $23-28 \%$ of the total, whereas the heat transferred in the form of radiation accounted for about $70-75 \%$. Through comparison of the amount of heat transferred by the heat transfer methods of conduction, convection, and radiation, it was revealed that most of the heat is transferred by radiant heat during heating. Comparing the total amount of heat applied 
Table 1. Comparison of amounts of heat transferred.

\begin{tabular}{|c|c|c|c|c|}
\hline \multirow{2}{*}{$\begin{array}{l}\text { Transfer } \\
\text { mode }\end{array}$} & \multirow{2}{*}{ Amount of heat transferred } & \multicolumn{3}{|c|}{ Comparison of heat transferred in box } \\
\hline & & Concrete & Brick & Wood \\
\hline Conduction & $\begin{array}{c}\text { Qcond }=\Delta Q / \Delta t=k 26.68^{\circ} \mathrm{C} * A * \Delta T / L \ldots \ldots \ldots \ldots \ldots \ldots \ldots \ldots(1) \\
k_{25^{\circ} \mathrm{C}}: \text { thermal conductivity of atmosphere at } 25^{\circ} \mathrm{C} \\
\quad(\text { Concrete : } 1.6 \mathrm{~W} / \mathrm{m} \cdot \mathrm{K}, \text { Brick : } 0.96 \mathrm{~W} / \mathrm{m} \cdot \mathrm{K}, \\
\quad \text { Wood(Fir) : } 0.12 \mathrm{~W} / \mathrm{m} \cdot \mathrm{K}) \\
A: \text { total cross sectional area of conducting surface }\left(\mathrm{m}^{2}\right) \\
\Delta T: \text { temperature difference }\left({ }^{\circ} \mathrm{C}\right) \\
\mathrm{L}: \text { length of conducting surface }(\mathrm{m})\end{array}$ & $\begin{array}{c}0.10 \mathrm{~W} \\
(0.84 \%)\end{array}$ & $\begin{array}{l}0.10 \mathrm{~W} \\
(0.8 \%)\end{array}$ & $\begin{array}{c}0.12 W \\
(0.67 \%)\end{array}$ \\
\hline Convection & $\begin{aligned} Q \operatorname{conv} & =h \operatorname{conv} * \text { Asurf } * \Delta T \ldots \ldots \ldots \ldots \ldots \ldots \ldots \ldots \ldots \ldots \ldots \ldots \ldots \ldots \ldots \ldots \\
h_{\text {conv }} & : \text { convection heat transfer coefficient } \\
A_{\text {surf }} & : \text { surface area }\left(\mathrm{m}^{2}\right) \\
\Delta T & : \text { temperature difference }\left({ }^{\circ} \mathrm{C}\right)\end{aligned}$ & $\begin{array}{c}3.38 \mathrm{~W} \\
(28.43 \%)\end{array}$ & $\begin{array}{c}2.98 \mathrm{~W} \\
(23.84 \%)\end{array}$ & $\begin{array}{c}4.52 \mathrm{~W} \\
(25.06 \%)\end{array}$ \\
\hline Radiation & $\begin{array}{l}\text { Qradi }=\sigma^{*} \varepsilon^{*} \text { Asurf } *(T 14-T 24) \ldots \ldots \ldots \ldots \ldots \ldots \ldots \ldots \ldots \ldots \ldots \ldots \ldots \ldots \ldots \ldots \\
\sigma: \text { Stefan-Boltzman constant }\left(5.669 \times 10^{-8}\right) \\
\epsilon: \text { emissivity of materials } \\
\quad \quad(\text { cement }: 0.94, \text { brick }: 0.93, \text { Wood }(\text { Fir }): 0.90) \\
A_{\text {surf }}: \text { surface area }\left(\mathrm{m}^{2}\right) \\
T_{1}, T_{2}: \text { temperature of two bodies }\left({ }^{\circ} \mathrm{C}\right)\end{array}$ & $\begin{array}{c}8.41 \mathrm{~W} \\
(70.73 \%)\end{array}$ & $\begin{array}{c}9.42 \mathrm{~W} \\
(75.36 \%)\end{array}$ & $\begin{array}{c}13.4 \mathrm{~W} \\
(74.27 \%)\end{array}$ \\
\hline & Total & $\begin{array}{l}11.89 \mathrm{~W} \\
(100 \%)\end{array}$ & $\begin{array}{c}12.5 \mathrm{~W} \\
(100 \%)\end{array}$ & $\begin{array}{l}18.04 \mathrm{~W} \\
(100 \%)\end{array}$ \\
\hline & Efficiency & $21.62 \%$ & $22.73 \%$ & $32.8 \%$ \\
\hline
\end{tabular}

Table 2. Temperature change of water and vial

\begin{tabular}{cccccc}
\hline & $\begin{array}{c}\text { Temperature of } \\
\text { water } \\
\text { (Initial) }\end{array}$ & $\begin{array}{c}\text { Temperature of } \\
\text { water } \\
\text { (after 3 hours) }\end{array}$ & $\begin{array}{c}\text { Temperature of } \\
\text { vial } \\
\text { (Initial) }\end{array}$ & $\begin{array}{c}\text { Temperature of } \\
\text { vial } \\
\text { (after 3 hours) }\end{array}$ & $\begin{array}{c}\text { Total energy } \\
\text { transferred to Vial } \\
\text { and Water (kJ) }\end{array}$ \\
\hline \hline Concrete & 14.5 & 20.4 & 14.3 & 20.1 & 21.5 \\
Brick & 12.9 & 21.2 & 12.6 & 24.6 & 2.09 \\
Wood & 12.5 & 24.7 & 12.6 & 3.04 \\
\hline
\end{tabular}

to each structure, wooden models accounted for the most as $32.8 \%$ and showed the least heat loss, while concrete and masonry models showed more heat losses as $23.8 \%$ and $22.7 \%$, respectively.

The water installed in the building model can be compared with a human body which consists of water about $70 \%$ or more, and this study was proceeded by assuming the temperature change of the water in each model as the wind chill temperature. After hanging a beaker containing water in each material model, it was installed on an electric ondol panel. Then, heating and cooling were repeated at $40^{\circ} \mathrm{C}$ every 3 hours, and the temperature was measured for 6 hours. As shown in Table 2, after 3 hours of heating, the temperature of water and beaker were the highest in the wooden model at $24.7^{\circ} \mathrm{C}$ and $24.6^{\circ} \mathrm{C}$, respectively, followed by concrete model at $20.4^{\circ} \mathrm{C}$ and $20.1^{\circ} \mathrm{C}$, and masonry model at $21.2^{\circ} \mathrm{C}$ and $21.5^{\circ} \mathrm{C}$. 
Analysis of Heat Transfer Characteristics by Material Based on Closed Conditions Using Acrylic Hemispheres (II): Comparison by Type of Building Structural Materials

$Q=m c \Delta T=(m c \Delta T)_{\text {water }}+(m c \Delta T)_{\text {vial }}$

$m$ : Mass of water and glass beaker $(\mathrm{g})$

$c \quad$ : Specific heat (water : $4.18 \mathrm{~kJ} / \mathrm{kg}^{\circ} \mathrm{C}$, vial : 0.84 $\mathrm{kJ} / \mathrm{kg}^{\circ} \mathrm{C}$ )

$\triangle T:$ Temperature variation of water and glass beaker $\left({ }^{\circ} \mathrm{C}\right)$

It was quantified to compare the total energy used to increase the temperature of the water and the glass bottle, and the total energy was compared using the following equation.

\section{CONCLUSION}

In this study, the effects of the types of building materials on the indoor temperature environment and heat transfer characteristics in a closed environment were compared and analyzed. The wooden model had the highest amount of energy transferred to the wall and the water installed inside the building model during heating, which proved to be the best material for efficient use of energy. It is expected to increase the energy efficiency inside the building when wood is used as the building structure.

1. For insulation properties by material, wood showed higher insulation performance than that of masonry and concrete model, and also less heat loss.

2. The largest amount of energy received by the glass bottle and water inside the model was shown in the wooden model. Assuming the glass bottle and water as human, this indicates that human can feel the warmest in the wooden structure.

As for heat transfer method by material, the largest amount of heat was transferred by heat radiation, followed by convection flow, and heat conduction. Most of the heat was achieved by heat radiation. The wooden model transferred the largest amount of heat, and through this, it was confirmed that the heat loss was the least.

\section{ACKNOWLEDGMENT}

This study was carried out with the support of 'R\&D Program for Forest Science Technology (Project No. 2020161C10-2020-AD01)' provided by Korea Forest Service (Korea Forestry Promotion Institute).

\section{REFERENCES}

Chang, K.K. 2003. Environment-friendly wood house. Review of Architecture and Building Science 47(5): 33-36.

Jang, J.H. 2018. The increasing number of detached houses in Seoul and its related characteristics. Ph.D. Thesis, Seoul National University, Korea.

Jang, J.H., Lee, M., Kang, E.C., Lee, S.M. 2017. Characteristics of low density firberboards for insulation material with different adhesive (I): Thermal insulation performance and physical properties. Journal of the Korean Wood Science and Technology 45(5): 580-587.

Jang, J.H., Lee, M., Kang, E.C., Lee S.M. 2017. Characteristics of low density fiberboards bonded with different adhesives for thermal insulation (II): Formaldehyde-Total volatile organic compounds emission properties and combustion shapes. Journal of the Korean Wood Science and Technology 45(5): 580-587.

Jang, S.K., Seo, S.Y., Park, H.J., Lim, J.Y., Lim, J.H., Lee, W.S. 2007. TVOC emission by test period from liquid phase building materials. Journal of Korean Society for Indoor Environment 4(2): $140-153$

Kang, Y.J., Lee, J.H., Lee, H.Y., Kim, S.M. 2017. Heating and cooling energy demand evaluating of standard houses according to layer component of 
masonry, concrete and wood frame using PHPP. Journal of the Korean Wood Science and Technology 45(1): 1-11.

Kim, S.H., Yu, S.G., Seo, J.K., Kim, S.M. 2013. Thermal performance of wooden building envelope by thermal conductivity of structural members. Journal of the Korean Wood Science and Technology 41(6): 515-527.

Lee, H.H., Bender, D.A. 2009. Far infrared emissivity of wood material-comparing the three heat transfer modes of wood box and aluminum box. Journal of the Korean Wood Science and Technology 37(5): 440-450.

Lee, T.G., Yoo, D.W. 2018. A study on the characteristics of low energy houses in Korea and abroad by structure and energy performance. Architectural Institute of Korea 38(2): 32-33.

Ozcan, C., Korkmaz, M. 2019. Determination of relationship between thermal and mechanical properties of wood material. Journal of the Korean Wood Science and Technology 47(4): 408-417.

Pang, S.J., Lee, B.J., Jeong, G.Y. 2017. Insulation saving effect for korean apartment house using Cross-Laminated Timber (CLT). Journal of the Korean Wood Science and Technology 45(6): 846-
856.

Park, J.M., Kim, D.H., Suh, D.J. 2012. Recent research trends for green building thermal insulation materials. Clean Technology 18(1): 14-21

Seo, J.K., Kang, Y.J., Kim, S.M. 2016. Wood thermal conductivity database construction for the application of building energy simulation. Journal of the Korea Furniture Society 27(2): 122-127.

Seo, J.K., Jeong, S.G., Kim, S.M. 2017. Thermal bridge and heat transfer analysis for each part in residential building according to construction of wood-based finishing material. Journal of the Korean Wood Science and Technology 45(3): 343-359.

Yang, S.M., Lee, H.J., Kang, S.G. 2020. Analysis of heat transfer characteristics by materials in closed conditions using acrylic hemisphere (I): Comparison of interior finishing materials. Journal of the Korean Wood Science and Technology 48(2): 217-230.

Yang, J.M., Cheon, D.Y. 2013. A study on how to improve the performance of the wall between rafters in hanok. International Journal of Ondol 2013: 283-290. 
Analysis of Heat Transfer Characteristics by Material Based on Closed Conditions Using Acrylic Hemispheres (II): Comparison by Type of Building Structural Materials

\section{APPENDIX \\ (Korean Version) \\ 아크릴 반구를 이용한 밀폐조건에 따른 재료별 열 이동특성 분석(II): 건축구조재 종류에 따른 비교}

초록 : 본 연구에서는 시멘트, 벽돌, 목재를 이용한 건축모형을 이용하여 직경 $900 \mathrm{~mm}$ 의 밀폐된 환경 속에서 3일간 온도와 상대습도 측정을 통하여 건축소재의 종류에 따른 실내 온도 환경에 미치는 영향과 열 이동 특성에 대해서 비교분석하였다. 건축 모형 내부에 설치된 물은 실내에 있는 사람을 나타냈으며 사람에게 어떤 영향을 미치는지 평가하고자 사용되었다. 목조 건축 모형은 시멘트, 벽돌 건축물 보다 보온성이 높아 열 손실이 가장 낮은 것으로 나타났다. 각각의 건축 모형의 열적 쾌적성은 온도와 상대습도를 이용하여 산출하였으며 목조 건축 모형은 시멘트, 벽돌 건축 모형보다 더 쾌적한 환경을 조성하는 결과를 도출하였다.

\section{1. 서 론}

오늘날 우리나라를 비롯한 세계 각국에서는 다양한 재료가 건축자재로 사용되면서 이에 따라 각각 특징적인 실내 환경을 나타낸다. 보통 동서양은 지역의 기후, 환경, 문화적 특성에 의해서 사용되는 건축자재의 차이를 보이고 있다.

예로부터 유럽은 석재문화가 발달되어 있어 석재를 이용한 건축양식이 주를 이루고 있으며 미국은 풍부한 산림자원으로 인하여 유럽과 달리 목재자원을 활용한 목조주택이 주를 이루고 있다. 동아시아지역 중 일본은 빈번한 지진 피해를 받는 지리적 특성으로 인하여 철근-콘크리트로 지어진 고층빌딩을 제외하고는 내진성능이 우수한 목조주택이 주를 이루고 있다. 국토교통부 주택유형별 건설실적통계자료에 따르면 2015년 기준 총 765,328 호의 주택이 건설되었으며 이 중 아파트는 534,931호(전체 주택건설실적 중 $69.9 \%$ )가 건설되었다. 이는 전체 주거용 건축물 중 $70 \%$ 이상을 철근-콘크리트 구조인 아파트로 시공하고 있다는 의미이다. 그러나 최근 건축자재로부터 실내 포름알데히드, 휘발성유기화합물 등과 같은 실내 공기질 오염물질 방출 (Jang et al., 2007)에 대한 관심도가 높아지면서 소비자는 친환경적이며 실내쾌적성을 중시하는 방향으로 주거문화가 변화되고 있으며 이는 단독주택의 수요 증가로 이어지고 있다(Jang, 2018). 국내의 단독주택의 구조형식은 조적조, 철근콘크리트조, 목조주택으로 구분되며, 조적조는 내구성, 내화성이 뛰어나다는 장점을 지니고 있어 가장 널리 사용되는 구조방식이지만 온습도 조절능력이 떨어진다는 단점을 가지고 있다. 아파트, 공동주택 건축에 많이 사용되는 철근-콘크리트조는 구조적으로 안정성이 뛰어나 가장 일반화된 주택구조이다. 철근-콘크리트 구조는 단독주택에서는 시공사례가 적으며(Kim et al., 2017), 이는 국내의 저에너지 건축(패시브하우스협회등록)의 구조와 관련이 있으며 저에너지 건축물 101 건 중 목구조 56 건(55.4\%)을 차지하며 철근콘크리트조 37 건(36.6\%), 철골조 6건(5.9\%), 혼합구조 2건(2\%) 순으로 목구조에 비하여 철근콘크리트조의 비율이 낮다 (Lee et al., 2018).

목조주택은 우리나라 전통한옥처럼 목재를 주요 구조부재로 사용하며, 우수한 단열성능과 조습성능으로 재실자에게 긍정적 인 영향을 줄 수 있다는 연구결과를 통해 녹색 건축물로서 주목받고 있는 주택구조이다(Kim et al., 2013). 목조주택의 주요 자재인 목재는 건축 재료로써 지속가능한 자원이며 에너지 효율적인 자재 중 하나로 주목(Seo et al., 2016; Seo et al., 2017; Jang et al., 2017; Jang et al., 2017; Ozcan et al., 2019; Pang et al., 2017; Yang et al., 2020)받고 있다. 또한 다양한 구조재 및 실내외 인테리어 마감재와 가구 장판 등 다양한 복합재료도 목재의 활용사례가 증가하고 있다(Chang, 2003).

따라서 본 연구에서는 국내 주요 건축구조인 콘크리트조, 조적조, 목조주택 3가지를 대상으로 아크릴 반구를 이용하여 풍향, 강우 등의 기후적인 변수의 영향을 제한한 건축구조물의 내·외부 온도차에 의한 단열성능과 온돌판넬을 이용한 바닥 난방에 따른 건축구조물 간 열 이동 방식의 도출을 통하여 건축자재간 특성을 비교분석하고자 한다.

\section{2. 재료 및 방법}

\section{1. 공시재료}

본 연구에서는 반구를 이용한 밀폐조건에서의 건축구조재의 종류에 따른 단열 및 열 전달방식 분석을 위해 국내 주요 건축자 재인 시멘트, 벽돌, 목재를 이용하였으며, $360 \mathrm{~mm} \times 230 \mathrm{~mm} \times 174 \mathrm{~mm}$ (실내공간 $240 \mathrm{~mm} \times 110 \mathrm{~mm} \times 114 \mathrm{~mm}$ ) 크기의 건축모형을 제작하였다. 이때 제작된 건축물의 벽체 두께는 $38 \mathrm{~mm}$ 이었다. 


\subsection{1. 시멘트}

경남 소재의 $\mathrm{H}$ 사로부터 분양받은 시멘트 분말은 가정용 시멘트로 모래 혼합 없이 사용가능한 제품을 사용하였다. 타 재료로 제작된 건축구조물과의 동일한 규격으로 제작하기 위하여 성형틀(외부: $436 \mathrm{~mm} \times 3,060 \mathrm{~mm} \times 250 \mathrm{~mm}$, 내부: $360 \mathrm{~mm}$ $\times 230 \mathrm{~mm} \times 174 \mathrm{~mm}$ )을 제작하여 사용하였으며, 제작 후 2주간의 양생기간을 거쳐 제작된 건축모형을 본 연구에 사용하였다.

\subsection{2. 벽돌}

국내 조적조 건축에 사용하는 벽돌을 대전소재의 $\mathrm{T}$ 사로부터 분양받아 사용하였으며, 콘크리트 구조물에 사용한 시멘트를 이용하여 벽돌을 접착시킨 후 2주간의 양생기간을 거쳐 제작된 건축모형을 본 연구에 사용하였다.

\subsection{3. 목재}

경골목조주택의 기본 재료인 2" $\times 4^{\prime \prime}(38 \mathrm{~mm} \times 89 \mathrm{~mm})$ 규격의 $\operatorname{Fir}($ 전나무)를 이용하였으며 레그스크류를 이용한 건축모형을 제작하여 본 연구에 사용하였다. 이때 제재목의 접합 틈새로부터 손실되는 열을 방지하기 위하여 $3 \mathrm{M}$ Extreme Sealing tape $4411 \mathrm{~N}$ 을 이용하여 접합틈새를 마감하였다.

\section{2. 아크릴 반구를 이용한 건축모형의 단열실험 방법}

건축(콘크리트, 벽돌, 목재) 모형을 3 개의 반구 내에 동일한 위치에 설치하였으며 건축구조물의 내외부 변화 측정을 위하여 5 지점에 온도센서를 설치하여 시간경과에 따른 온도변화를 측정하였다. 온도센서 부착 위치는 Fig. 4 와 같다. 제조된 건축구조물 모형의 외기에 의한 영향을 제거하기 위하여 지름 $900 \mathrm{~mm}$ 에 두께 $9 \mathrm{~mm}$ 의 투명 아크릴 반구 공간 내에 설치하여 본 연구를 진행하였다.

제작된 모형은 충남대학교 내 옥외에 설치하였으며 3일간(2017년 6월 8일부터 10일까지) 시간경과에 따른 반구 내외 부의 온도, 건축모형 내·외부 대기 온도 등의 온도변화를 측정하였다. 이때 온도 측정주기는 10 분으로 Thermal data logger (BTM-4208SD, Lutron)를 이용하여 측정하였다.

\section{3. 온돌판넬을 이용한 건축 모형의 열이동 방식 비교 실험방법}

목재, 벽돌, 시멘트를 사용하여 각각 제작한 $360 \mathrm{~mm} \times 230 \mathrm{~mm} \times 174 \mathrm{~mm}$ 의 건축모형 내부에 $50 \mathrm{ml}$ 용량의 비커에 물을 담아 건축모형 천장의 중앙에서 $5 \mathrm{~cm}$ 떨어지도록 피아노 줄을 사용하여 설치하였다. Fig. 5 와 같이 7 곳의 온도 측정 지점(내부공 기, 내벽 표면, 물병표면, 물 내부, 외벽 표면, 외부 공기)에 Thermal data logger (BTM-4208SD, Lutron)를 설치한 후, 구조물을 전기 온돌판넬(삼보전기온돌판넬 $\mathrm{UH}-\mathrm{A}$ )위에 비치하고 실리콘으로 밀폐하였다. 사용한 온돌판넬의 온도를 $40^{\circ} \mathrm{C}$ 로 세팅한 후 가열을 시작함과 동시에 측정을 시작하여 3 시간 가열, 3 시간 냉각(미가열)의 과정을 반복하여 가열과 냉각을 총 2 회 반복, 즉 총 12 시간 동안 10 분단위로 온도를 측정하였다. 가열과 냉각시간은 1 일 24 시간 기준 12 시간 태양열에 의한 가열(주간), 12 시간 냉각(야간)을 시뮬레이션하기 위하여 진행하였으며, 특히 가열 및 냉각에 따른 최고-최저온도차를 통한 건축구조물 모형 내 열 이동특성 분석을 하고자 하였다. 이때 실험은 일사가 없는 $20 \pm 3^{\circ} \mathrm{C}$ 온도조건의 공간에서 실시하였다.

\section{3. 결과 및 고찰}

\section{1. 아크릴 반구를 이용한 건축모형의 단열실험 결과}

3.1.1. 소재별 건물 외벽·내벽 온도 비교

건축모형의 종류에 따라 반구 내 대기의 온도는 건축구조재료의 종류에 따른 차이는 나타나지 않았으며, 반구 내부 및 건물 모형의 외벽온도는 Fig. 6, 건물 모형의 내부온도는 Fig. 7과 같다. 시간 경과에 따라 건축구조물의 외벽 및 내벽 온도 그래프 상승 하강은 동일한 경향을 나타냈으나, 건축모형 외벽 온도는 조적조(masonry structure)>콘크리트(concrete building)> 목조(wooden building) 순으로 나타냈으며, 최대-최저 온도 차이는 외벽온도와 동일하게 조적조>콘크리트>목조 순의 결과를 나타냈다. 건축물의 외벽의 최대-최저 온도 차이는 일사에 의한 건축물의 온도 상승과 일사가 없는 조건에서의 건축물 외벽의 온도 하강을 확인하였다. 이는 건축 재료에 따라 동일 일사조건에서 건축소재 열전도율(Thermal conductance)에 따른 외벽으로 부터 내벽으로의 열전달 차이를 나타낸 것으로 판단된다.

3.1.2. 소재별 외벽-내벽 온도차 비교

소재별 단열성능 평가를 위해 소재별 외내벽 온도차는 Fig. 8에 나타냈다. 소재별 외벽과 내벽의 온도 차이는 건축 구조물의 단열성능을 의미한다. 단열성은 열의 이동을 막아주는 정도, 즉 외벽의 온도가 높아졌을 때 내벽의 온도에 영향을 덜 주는 
Analysis of Heat Transfer Characteristics by Material Based on Closed Conditions Using Acrylic Hemispheres (II): Comparison by Type of Building Structural Materials

정도를 의미하며 외벽-내벽의 온도 차이가 클수록 단열성이 높다는 결과를 해석할 수 있다(Yang et al., 2013). 외벽과 내벽의 온도 차이는 목조 $\left(\right.$ 약 $\left.40^{\circ} \mathrm{C}\right)>$ 콘크리트조 $\fallingdotseq$ 조적조 $\left(\right.$ 약 $\left.20^{\circ} \mathrm{C}\right)$ 로 나타냈으며 이는 목조모형이 시멘트와 콘크리트 구조물과 동일한 열을 받지만, 내부로 전달되는 열의 양이 적음을 나타냈다. 목조가 조적조와 콘크리트조 보다는 단열성능(insulation performance)이 높다고 판단되며, 이는 재료별 열전도율과 밀접한 관련이 있다. 목재의 열전도율은 0.1-0.2 W/m·K로 벽돌 0.4-0.8 W/mKK, 콘크리트 0.15-2.5 W/mK의 열전도율(Park et al., 2012)에 비하여 낮은 열전도율을 가져 상대적으로 단열성능이 높다고 판단할 수 있다. 또한 건축모형의 구조물 두께는 목조, 콘크리트, 조적조 모두 동일하므로 열관류율은 구조물의 원재료의 열전도율과 밀접한 관련이 있으며 이는 외벽-내벽의 온도차이의 결과와 동일한 결과를 유추할 수 있다.

\section{2. 온돌판넬을 이용한 건축소재별의 열 이동 방식 비교}

앞선 아크릴 반구를 이용한 건축모형의 단열실험 결과를 통하여 건축소재별 내·외부 온도차에 의한 단열성능의 차이를 확인하였으며, 바닥난방에 따른 건축소재별 열전달방식 및 실내 거주자의 쾌적감(thermal confort) 비교를 위한 세 가지 건축 구조물을 이용하여 난방 시 열전달 방식과 유리병과 물에 가해진 에너지량을 비교하였다. 난방 시 열전달 방식에 따른 이동 열량의 결과는 Table 1의 계산식(Lee et al., 2009)에 의하여 산출된 결과와 같으며, 발생된 열량(온돌판넬 발생 열량 : $55 \mathrm{~W}$ ) 중 목재구조물은 약 $18 \mathrm{~W}(32.8 \%)$, 콘크리트조는 $11.9 \mathrm{~W}(23.8 \%)$, 조적조는 $12.503 \mathrm{~W}(22.7 \%)$ 의 에너지가 전달되었다. 전달된 열은 모든 소재에서 복사, 대류, 전도 형태로 전달되었으며 전도열은 전체의 약 $1 \%$ 정도로 낮았고, 대류열은 전체의 약 $23-28 \%$ 인 반면, 복사의 형태로 이동한 열은 전체의 약 70-75\%를 차지하였다. 열 이동 방식인 전도(conduction), 대류(convection), 복사 (radiation)에 의한 이동 열량의 비교를 통하여 난방 시 열 이동은 대부분은 복사열에 의해 이동되는 것으로 나타났다. 각 구조물에 가해진 총 열량을 비교해보면 전체에 목조 모형이 가장 많은 $32.8 \%$ 를 차지하며 가장 적은 열손실을 나타냈고, 콘크리트조와 조적조 모형은 각각 $23.8 \%, 22.7 \%$ 로 더 많은 열손실을 보였다.

건축모형 내에 설치된 물은 약 $70 \%$ 이상 수분으로 구성되어 있는 인체로 비교할 수 있으며, 각각의 모형 내에 설치된 물의 온도 변화는 체감온도(wind chill temperature)로 가정하여 본 연구를 진행하였다. 각 소재별 모형 속에 물이 든 비커를 매단 뒤 전기온돌판 위에 설치하여 $40^{\circ} \mathrm{C}$ 의 온도를 3 시간 주기로 가열-냉각을 반복하였으며, 6 시간 동안 온도를 측정하였다. Table 2에 나타난 바와 같이 세 시간 가열한 후 물과 비커의 온도는 각각 목조에서 $24.7^{\circ} \mathrm{C}, 24.6^{\circ} \mathrm{C}$ 으로 가장 높았고, 콘크리트조 는 $20.4^{\circ} \mathrm{C}, 20.1^{\circ} \mathrm{C}$, 조적조는 $21.2^{\circ} \mathrm{C}, 21.5^{\circ} \mathrm{C}$ 로 목재에 비해 온도가 낮았다.

물과 유리병의 온도를 높이는데, 사용된 총 에너지를 비교하기 위하여 수치화하였으며, 다음의 식을 이용하여 총 에너지를 비교하였다.

$$
\begin{aligned}
& Q=m c \Delta T=(m c \Delta T)_{\text {water }}+(m c \Delta T)_{\text {vial }} \\
& m: \text { Mass of water and glass beaker (g) } \\
& c \quad: \text { Specific heat (water : } 4.18 \mathrm{~kJ} / \mathrm{kg}^{\circ} \mathrm{C} \text {, vial : } 0.84 \mathrm{~kJ} / \mathrm{kg}^{\circ} \mathrm{C} \text { ) } \\
& \triangle T: \text { Temperature variation of water and glass beaker }\left({ }^{\circ} \mathrm{C}\right)
\end{aligned}
$$

모형 내부에 물의 온도를 높이는데 사용된 에너지의 최대-최소값의 차이는 약 $1.5 \mathrm{~kJ}$ 이었으며, 목조모형 내의 물에 가장 많은 에너지를 받았으며, 콘크리트조 모형 내의 물이 가장 적은 에너지를 받은 것으로 나타났다. 실제 건축물에 적용하면 인체에 가해지는 열은 목조모형이 가장 많았으며, 이는 재실자가 가장 따뜻함을 느낄 수 있다고 판단된다.

\section{4. 결 론}

본 연구에서는 밀폐된 환경 속에서 건축소재의 종류에 따른 실내 온도 환경에 미치는 영향과 열 이동 특성에 대해서 비교분석 하였다. 목조모형이 난방 시 벽체로 전달된 에너지량과 건물모형 내부에 설치된 물로 열전달량이 가장 높았으며, 에너지를 효율적으로 사용하는데 최적 재료임을 확인할 수 있었고, 이는 건축 구조재를 목재로 사용 시 건물 내부 에너지 효율을 높일 것으로 판단된다.

1. 소재별 단열성은 목재의 단열성이 조적조와 콘크리트조에 비하여 높은 단열성능을 나타냈으며 열손실 또한 적게 나타났다.

2. 모형 내부의 유리병과 물이 받은 에너지의 양은 목조모형에서 가장 높게 나타났으며, 이는 유리병과 물을 사람으로 가정하 였을 때 목조건물에서 인간이 가장 따뜻함을 느낄 수 있다.

3. 각 소재별로 열을 전달하는 방식은 열복사, 열대류, 열전도의 순서로 가장 많은 열을 전달하였고 대부분의 열이 열복사에 의해 이루어졌다. 각 소재별로는 목조모형에서 가장 많은 열을 전달하였고, 이를 통해 열손실이 가장 적은 것을 알 수 있었다. 